\title{
THE POLITICAL CULTURE; POLITICIAL SOCIALIZATION AND ACCULTURATION
}

\author{
Martian IOVAN, Ph. D. \\ "Vasile Goldis" Western University of Arad \\ E-mail: miovan@uvvg.ro
}

\begin{abstract}
In this article, the author, after having comparatively analyzed senses and significations of the concept of politic culture, as stated by several renowned authors in the world of science, proceeds to a differentiation of general political culture from those political cultures that are integrated into the lives of contemporary political agents (subcultures, political countercultures, marginal cultures, political cultures of public policy makers etc.) which coexist on the territory of a state.

Using praxeological and systemic approaches, the author discusses the place and role of contemporary ideologies in their quality as a directional and dynamogenic factor in political practices, as well as political socialization and acculturation as methods of reproducing and developing political culture in accordance with the necessities imposed by the global development of society and by its subsystems. The formation of a solid political culture, through education and communication in general, both at individual and at social level, conditions the maturation of democracy, and the launching of public policies likely to solve individual and community issues.
\end{abstract}

Keywords: participative political culture, subcultures and countercultures, socialization, acculturation, ideology.

\section{Introduction}

The concept of culture is a polysemantic one; in specialized literature there is a wide range of senses and significations attributed to this term, which have been stated in various definitions: nominal, genetic, structural, functional, historical, psychological, ostensive, normative etc. In his work, "Sociodynamique de la culture" - 1967, Abraham A. Moles observed the existence of over 250 definitions. And if we should consider different segments of culture in society at large, different subcomponents or historical moments of the morphology of culture, then the number of definitions, descriptions and nuances would tend to increase exponentially.

In everyday language, the applications of such expressions as: cultured person, high culture, mass culture, average culture, popular culture, elite culture, classic culture, modern culture, political culture, universal culture etc. are often discussed. All these make us question the real meaning of culture. Certainly, the modern sense of the concept of culture was first used by Edward B. Tylor and defined in his work "Primitive culture" - London, 1871: "Culture, or civilization, taken in its broad, ethnographic sense, is that complex whole which includes knowledge, belief, art, morals, law, custom, and any other capabilities and habits acquired by man as a 
Iovan, M., (2015)

The political culture; political socialization and acculturation

member of society." Thus understood, culture is a result of mental, spiritual and organizational development of society. In the century, the term of 'culture' was correlated to, and almost identified with that of civilization. A. Comte, for instance, believed that civilization resided in the development of the human spirit, in development of the action of man on nature which is, in fact, the direct consequence of the development of spirit. Subsequently, O. Spengler would maintain that civilization was the inevitable destiny of a culture, the most exterior and most artificial stage that the human species can reach. Starting from such connotation, the last century knew an ample recurrence of the expressions: "material culture" and "spiritual culture", "explicit culture" and "implicit culture" (spiritual values, attitudes, ideals, symbols etc.), "real culture" and "ideal culture", "subculture" and "counterculture", cultural transmission, acculturation etc.

Regardless of the type of discourse referring to culture, subsidiarity all sociologists agree on a few defining notes of the concept. Thus, ideas such as: culture is a socio-historical product that is the gauge of human beings, culture is what differentiates humans from all the other species of the biosphere, culture comprises all acquisitions of the agents of social action resulting from creation, culture is all that is to be learnt throughout one's social life and transmitted from generation to generation, it is a learned and socially transmitted inheritance etc., reunite the agreement of anthropologists, sociologists, humanists. Today it is evident to all those who study society and its history that any human community, any agent of social practice (individual, company, political party, state, political elite etc.) possesses a specific, concrete culture, which influences and determines the total development of its composing members. Upon birth, each human individual finds a preset culture (models, patterns, paradigms, codes, symbols, habits, traditions, norms, mentalities, values). The human will assimilate and acquire humanity while becoming a cultural subject, while internalizing cultural values. This is obtained through education and self-education, through the action of socialization factors. Through cultural transmission (what Ralph Linton called the "social heredity of the members of a society") human beings became the dominant species on Earth. In such a system of reference, political culture holds its specific place and plays a privileged part.

The financial, economic, social and cultural crisis started two years ago on a worldwide scale, shifts the focus again on the issues regarding the structure and dynamics, the functioning and efficiency of political culture. It is not so much the theoretical - philosophic, sociological and anthropological dimensions regarding political culture that come first in debates, as its practical, behavioral and pragmatic components. This reality is illustrated by the strong development in the system of political sciences, in public policies, in administration science and the management of state institutions. The imperious need for any state institution (government, ministries, directorates, agencies, councils, presidency, local public authorities etc.) 
The political culture; political socialization and acculturation

is to possess such a political culture (which is always multi- and interdisciplinary) as to be capable to launch the appropriate policies for solving community problems and, first and foremost, those on the public agenda. Without a political culture at general state level and at the level of each public authority within the European Union or within its composing states, on a national, regional and local scale, which would be solidly based and operational, the efficiency of designing and implementing public policies cannot be guaranteed, neither can the ongoing crisis come to a close.

Given the situation, it is necessary to make a distinction of principle between the theoretical, systematic political culture of state institutions, which is transmitted and assimilated officially in relevant faculties, postgraduate studies, doctoral schools, and the political culture of the community, of the masses, of the citizens. The latter is driven by parties, interest groups, pressure groups, mass-media institutions, the system of communication between the government and the governed. The current crisis will certainly have among its results: the development of the functional political culture of the agents involved in finding solutions to the problems with which human communities are confronted and their practical finalization, the invention of new political instruments, the value-related detachment of the role of knowledge and, implicitly, of media coverage, the shift of place and role in hierarchy not only by political actors, but also their ideological doctrinal orientations, a new perspective on using force in international relations, in the globalization process as method of overcoming the crisis etc.

Here are a few aspects which place the senses and significations of the concept of political culture at the center of the scope of interests for researchers in the field of political, economic, socio-human, juridical sciences, but also for those in transdisciplinary fields, such as political philosophy, philosophy of law or political anthropology.

\section{Significations of the concept of political culture}

The expression "political culture" was introduced in political science during the last half of a century, especially in the works of American research. Naturally, there had been generic terms covering the same reality centuries before this expression was coined, which were used in an encyclopedic discourse, with a contemplative or metaphysical connotation. But this time the expression so defined (from the standpoint of pragmatic philosophy) as to be used in comparing contemporary systems and regimes, in recording tendencies, rules and mechanisms of intervention in political life, in the sense of deepening democracy, enhancing the efficiency of governing activities and public affairs management. The first empirical sociological studies were dedicated to the political culture of democracy and of the social processes and structures sustaining it. Gabriel A. Almond and Bingham G. Powell wrote, in 1966, that: "Political culture is the pattern of 
Iovan, M., (2015)

The political culture; political socialization and acculturation

individual attitudes and orientations toward politics among the members of a political system. It is the subjective realm which underlies and gives meaning to political actions. Such individual orientations involve several components, including (a) cognitive orientations, knowledge accurate or otherwise, of political objects and beliefs; (b) affective orientations, feelings of attachment, involvement, rejection, and the like, about political objects; and (c) evaluative orientation, judgments and opinions about political objects, which usually involve applying value standards to political objects and events". In other words, political culture stands for the entire network of orientations, attitudes, convictions and values by which the individual relates to the political system. In the same spirit, Lucian W. Pye regarded political culture as a set of beliefs and attitudes orienting political life and providing the rules intended to regulate political behavior. It entails both political ideals, and the norms with which politics operates. Likewise, the English political scientist Al. Ball believed that political culture is generally composed of attitudes, beliefs, emotions and reality values linked to political life, whereas Y. Schemeil (France) preferred the expression "political cultures", which would suggest cultural plurality, for, in reality, there is no one political culture; there can be, however, common notes to these multiple political cultures: the attitude towards the political system, political beliefs and significations that are pertinent to a collectivity.

All these definitions of political culture have in common the fact that they prevalently illustrate the subjective dimension of political practice, they explicitly refer to the psychological dimensions of politics, which are, essentially, the following three: a cognitive dimension (knowledge, explanations, interpretations, anticipations referring to internal and external political events); an affective or emotional dimension (expressed in affects, affective dispositions, feelings, passions etc.), which have an obvious role in forming attitudes and creeds, and an evaluative dimension, expresses in the judgments of value with regard to political events and processes, according to the scale of values to which the individual has adhered. Evidently, these three dimensions of political culture are systemically and functionally correlated, resulting in three states of mind that the population has about politics: approval, apathy and alienation. Depending on the way in which the cognitive elements of political culture combine with the affective and evaluative, these combinations may result, according to G. Almond and Sidney Verba, in the following types of political culture:

a) A parochial (local or provincial)political culture, specific to traditional societies, to communities that are unaware of the importance of national and world issues and have no interest in the values and mechanism of the national political system. This is the political culture of villages, ethnic groups, regions - where the church, the school and the town hall are key institutions. Knowledge, feelings and judgments of value are oriented toward these local structures. 
The political culture; political socialization and acculturation

b) A political culture of submission (subordination), corresponding to communities regulated by national values. Within these societies, the agents of political action are aware of the existence of a political system, but contend themselves on an attitude of passivity with regard to participating in political life and decision making processes. This is due to the fact they believe the political system to be thus built so as to protect their lives and personalities, without expressing initiatives and requirements to the state authority. That is, the system will work well, the advantages will be good for all citizens, if they comply with the decisions and regulations corresponding to an ethics of submission.

c) A participative political culture, which corresponds to democratic system and is the result of developed educational processes and a high extent of organization, also reflecting the political-social experiences that are specific to democratic countries. Citizens possess several subjective means and abilities, skills and dexterities for using them rationally, for the purpose of influencing decision making, the progress of political events, representation or for stopping those administrative decisions that would negatively affect their interests.

These types of political cultures coexist in contemporary society, they combine and influence each other, they fuse or intertwine among individuals who form the political community of that country. Thus, for instance, the citizens of a participative political society are not solely oriented towards active participation in politics, they are also subject to laws and authorities, as well as being members of a group with a parochial culture. The political orientations of an individual contain, to varying degrees, elements of parochial, submission and participative culture. Likewise, any particular political culture involves the same three types of elements, combined to specific proportions.

G. Almond and S. Verba conducted and ample research between 1958 and 1963, in five countries: the U.S.A., England, Italy, Germany and Mexico, on a sample population of 1,000 subjects, questioned in each country. The purpose of the research was to discover the cultural bases of democracy. Considering the degree of participation (expressed in practical performances) by citizens in the workings of a democratic system as a core value of political and civic culture, Almand Verba measured the level of political culture in each of the five countries, using the following indicators: the amount of political knowledge; the civic component; the modes of political action; the evaluation of the political system. The conclusion they reached, at that time, were: only the U.S.A. and England had reached the necessary degree of correlation between the primary structures of society (families, local communities etc.) and the national political structures which provide functionality to democratic participative culture. Italy and Mexico would have a parochial culture; Germany - one of submission. In societies where there is a rupture between political attitudes and social ones, there appears to be a political culture of alienation (Italy), either one of submission (Germany), or a dissident political culture (Mexico). Thus, 
Iovan, M., (2015)

The political culture; political socialization and acculturation

political culture has an impact on the political system to which it belongs. There is a democratic political culture - a pattern of political attitudes sustaining democratic stability, political modernization, in the sense of increasing the efficiency of governing activities. The citizens belonging to a democracy possess a rational active culture, which means that they are expected to be active in politics, to be guided by reason, and not by emotions, when approaching politics, to be well informed and base their decisions on careful thinking, on correlating individual interests to collective ones, on the ethics of responsibility. As long as citizens do not act according to the standards of rational-active culture, democracy has failed. Low levels of political culture, insufficient information, apathy, passivity among citizens are indicative of a weak democracy.

To these three types of culture are added, under the impulse of audio-visual means - as R.G. Schwartzenberg wrote, the "spectacle" political culture, which is damaging in a different way than the culture of submission. If the latter ensures professed dominance and admits open violence, the spectacle culture is nothing but simulation, artifice, parody. It is a deceptive representation of democracy, a simulacrum of participative culture. Individuals believe themselves to be free, active, and influential. They believe that they actors of the political system, when in fact they are not but spectators, deceived and deluded by the "game of politics" that is played on the TV screen and behind the voting booth curtain". Thus, the spectacle culture comes to insidiously replace participative culture, and the political spectacle replaces democracy, brining back into discussion the issue of man's political alienation, even in advanced democratic societies.

In another perspective - the praxeological one, political culture pertains to the subjects of political action, to those who are involved, direct or indirectly, in politics, are part of political life either as leaders or as followers, with the mention that in democratic societies the two statuses (leader, follower) are cumulated by most citizens. Political culture is a reality that is present in all societies organized according to political criteria, being the result of cumulative efforts by many generations, aimed at bringing about a social order in which the lives of individuals would be possible and guaranteed, and which would secure the requirements for a good functioning of the entire social body (people, nation, human collectivity), social progress and the development of the personalities of the members of that social body.

Being a component of a society's culture, political culture has the same structural components, but they gravitate around political values and guide political action, and the workings of the political system in a society. The immense diversity of politically organized human collectivities and the impressive variety of concrete political agents results in a pluralism of political cultures (for example: the political

DE GRUYTER OPEN
Journal of legal studies Volume 16 Issue 29/2015 ISSN 2392-7054. Web: publicatii.uvvg.ro/index.php/jls. Pages 26 - 47 
culture of Romanian elite, the political culture of the electoral body, the political culture of party X or Y, the political culture of ethnic minority A or B, the political culture of youth in general or of the youth affiliated to a party, the political culture of governors versus the governed, the political culture of those at power versus opposition, the political culture of pressure groups etc.). Behind concrete elements, specific to the culture individual political agents, common, general and essential elements of political culture can be traced and functionally correlated into a pattern. Its elements are:

a) Cognitive, by which the agent of political action reflects, understand, explains his political deeds, the politico-social universe, the possibilities and opportunities of his participation in political practice. Political knowledge, the amount of political-juridical information existing in society and, especially, in the experience of the agent of political action, have been internalized in the form of operational acquisitions, being both a resource and a means of political practice, which facilitate a conscious, rational, responsible and efficient action. Besides operational political information, in all contemporary cultures there is also knowledge, contemplative, speculative information, situated somewhere in the passive realm of knowledge and political culture. One cannot, however, exclude the possibility of updating this information, of transforming into an operational instrument, favorable to increasing the rationality and efficiency of political practice in certain social circumstances.

b) Axiological, by which the agents of political action (political leaders, political elite, parties, pressure groups, electorate etc.) evaluate, according to a certain criterion, facts and procedures of political practice, as well as their own performance, establishing a hierarchy and action priorities, determining utility, the sense of actions, the possibilities of political alliance etc. All these evaluations are essential for scheduling action, for creating strategy and tactics, but also for correlating the political agents' own actions "on the fly".

c) Creative, by which the agents of political action process the cognitive, affective, motivational and moral-volitional data which they possess in experience, constructing and developing new political values, solving issues made current by the flows of social events. All these involve creative efforts for adapting, constructing, and producing novelty; the creation of political values constitutes the nucleus of political culture, the factor that gives the measure of success in action and predetermines the historical importance of political actions.

d) Praxeological, used in the political action of values, such as: political agenda, strategies, tactics, political ideals, political means and resources, objects that undergo transformations (which, in connection to governing acts, become politicized), acts of legalization, decisions, control etc. All the components of political practice are contained within the scope of political culture and can be evaluated as values, pseudo-values and anti-values. Some pertain to the material, 
Iovan, M., (2015)

The political culture; political socialization and acculturation

others to the non-material (ideal) side of culture - each having specific, irreplaceable functions in political practice, in achieving the objectives of politics in general.

e) Communicational, concretized in the transmission political information between the two poles of political life: the governors and governed, between political society and civil society, between political elite and the citizen. The communicational realm overtook, by a wide margin, the other means of political practice (as source of efficiency, operativeness and importance) in the $20^{\text {th }}$ century. Hence, a growing interest by all governments in perfecting it. No politics is possible without communication, and this is especially true in the case of the democratic political system. The modernization of communication political systems proved to be necessary to the development of political life, to the transfer of political models through learning, imitation, education, through the action of the various factors of political socialization - processes occurring within the same human community or among different collectivities.

All these elements are organically correlated into a functional system of political culture, centered on a table of political values, specific to each society. Dominant political values are promoted and propagated by those who are at power. Liberal values may be "at the top" in on political system, while the values of socialdemocracy, or Christian democracy etc. may be prevalent in another. This emphasizes the role of ideologies as integral parts of political culture. But the political culture of a society must be evaluated not according to the content of ideology (in such a case, the political scientist would have to characterize cultures that are so different in superlative terms), but according to the performance of political practice, and especially according to the amount of good, justice, welfare, happiness and truth brought to the people by a concrete political system. This is due to the fact that the elements of political culture participate, directly or indirectly, in a network of circuits composing global political practice. A disparate element of political culture, even if it has a perfect individual quality, will be devoid of value if the political action integrating it does not yield the socially expected results. From this point of view, the political culture of a society has passive ("dead") and active elements, latent and manifest elements, "parasite" ("pseudo-values") elements and functional elements, lucrative and inhibitive elements, propelling and barking elements etc.

Political culture, part of the overall culture of society, has been and will remain a variable depending on the general progress of human communities. It is subject to transformations, and implicitly to development and modernization. Throughout this historical process, it has demonstrated its ambivalent role: political culture, in its development, favors, on the one hand the increase in the degree of human freedom and, on other hand, limits the freedom of humans. Political culture increases freedom because it enables the elaboration of more soundly based options and the 
choice from a rational offer of acceptable variants, favoring participation in political life in the light of anticipating long-term effects. At the same time, political culture liberates the citizens from the effort of permanently reinventing the mechanisms of participation in political life, from exerting control on the activity of decision-makers, contesting political acts etc., for these may be ensured through social learning, through political socialization, generating free time, necessary for explorations and creation. At the same time, developing culture limits the freedom of citizens, as people are not free to do what they want to. Laws, normative acts, as inventions of juridical culture, prevents citizens from engaging in certain types of actions (for example: founding a fascist part, making an assault on the city hall or the government headquarters or not failing to pay their taxes) and makes them act in a certain way or in accordance to certain standards. But political culture sets uneven limits (depending on one's affiliation to a class, wealth, sex, professional status etc.).

The political culture of an agent of political practice (political party, body of state, pressure group, community, organization etc.) has a certain inner structure and coherence, dependent on fundamental values, worldview, religious creed, ideological dominants present in the consciousness and imagination of political agents. One's worldview, approach to history, religious and doctrinal creed are as many criteria for political action in the sense of increasing the degree of order, solidarity, freedom and justice in society. From this standpoint, Nicolae Frigioiu observed that in human societies culture appears "as a factor of unity, both for personality traits, and for the different personalities and communities. Culture is first and foremost continuity and cohesion, for there is no culture without tradition." Consequently, the ideological creed, the order of values within political culture is what orients the development and functioning political cultures in society, they are responsible for the degree of coherence, efficiency and efficacy of the dynamogenic, attitudinal, evaluative and motivational components of the political culture of each participant (person or institution) in political.

Having ideational (knowledge, justifications, argumentations, political ideals, a specific view on society and the course it should take etc.), affective (affects, emotions, feelings, political passions etc.), motivational (motives, interests, convictions, aspiration levels etc.), volitional (attitudes, decision-making capacity, perseverance, power of action and reaction etc.) components and including a stock of political resources and instruments, the political culture of different agents and politically organized human communities cannot remain neutral; in its entirety political culture has a certain dynamic, a power to adapt, and react in interactions with other cultures, to impose certain decisions and norms. Essentially, political culture stands for struggle, commitment, practical effort, in order to preserve a socio - economic and cultural system, change it, or negate it. The political culture of the members of an organization, agent, or politically organized community is 
Iovan, M., (2015)

The political culture; political socialization and acculturation

based on the members' agreement or disagreement with the direction or strategy for which the efforts are made.

In a society or in a state, political culture is held by direct and indirect participants to political life, supporters of political actors and electors, that is, a great part of the electoral body; beside these, there are those with attitudes of apathy and alienation. It is evident that, in times crisis, as is the case now, objective motivations are create for increasing participation in political. In such a context, one must re-analyze the structure and functioning of political culture, it role, the relations between political awareness, ideologies, political agenda, political affectivity, political attitudes and volition, in order to find the most effective and appropriate procedures for modeling and using political culture in carrying out projects, strategies, and political agenda.

\section{The diversity of political cultures}

The pluralism of political cultures is expressed both on a planetary scale, in the differences between political societies, between political systems and regimes and peoples, and within one and the same society.

As regards the diversity of political cultures among societies, anthropological reports showed a considerable cultural diversity, regarding the material aspects of political culture, the organization of relationships among the members of society, values, norms, habits, political morals and taboos, political symbols, administrative-territorial organization etc. The emphasis of differences among political cultures made use of certain criteria: dominant values in the political system (the American political culture, for instance, and all other democratic cultures consider the human being, as individuality, to be a supreme value, the respect for human rights is the axiom of any political agenda, whereas in communist regimes, and in those involving command in general, priority is placed on collectives, on general interests, and not on individual personality); the economic structure, based on which capitalistic, socialistic and mixed political cultures were formed; the level of development rendered, among others, by the Gross Domestic Product per capita, depending one may talk about political culture in developed, averagely developed, underdeveloped, developing societies; historical, geographical or climatic criteria, depending on which one may talk about the political culture of insular and continental countries, of countries with warm, temperate and cold climate, of countries with millennial state traditions and countries with a shorter history of political life, of countries colonially dominated by France, in contrast to those dominated by Great Britain or Portugal. Sometimes, cultures were classified using the older division of Apollonian vs. Dionysian cultures. Thus, a Dionysian political culture would give vent to unchained imagination, frantic activities, participative passions, exaggerated sensibility, whereas the Apollonian one lays emphasis on rational sobriety, logical calculus, 
discretion, moderation, mechanical observance of laws, on the pre-eminence of collectivity over the individual.

The diversity of political cultures in human communities comes to testify to the innovative power of political elites and to the flexibility and versatility of institutions and political-juridical organizations. Just as the political cultures of different societies vary over space and time, the social segments composing a society may produce variety in political structure, especially in the modern and postmodern era, resulting in the political culture of the regime and the political culture of the opposition, the political culture of left (prevalently relating to the following values: equality, social justice, equity, solidarity, progress, the secular sense of human life, Republicanism, powerful state, unconditional social protection etc.), the political culture of the right (oriented by a different set of values: the preeminence of individuals over collectivity, human rights, defense of property, social order based on the law, promotion of naturally formed elites, belief in God, conservatism, anti-communism), a liberal, Christian-democrat, communist, nationalistic, conservative, ecologist etc. political culture. As in the last century, specialized literature still operates with such expressions as: "political culture of the masses", "political culture of the elite", "political culture of governors", "political culture of electors", "marginalized political culture", "political culture of consumption", "political culture of the assistential state", political culture of a majority within a national state, in the European Union etc. Political cultures have proliferated at an exponential rate due to the democratization of society, the generalization of compulsory education, the development of mass-media, the globalization of the information society. Extending the practices of creating and implementing public policies among thousands of political agents in the same country led to the formation of political cultures with highly individualize. In order to designate this variety of political culture within a society, the term of political subculture was introduced, with the expression of political cultures being sometimes used.

Political subcultures may be based in a social class, an ethnic or religious group etc. which, by reacting to the process of homologation and generalization of official political values, build their own systems of values, representing a sublimation of their needs, attitudes and lifestyle at the level of community life. Political subcultures summarize the worldview of collectivities guided by democratic values. As V. Magureanu showed, "they are not opposed to official values; they do not contest these values, but they institute a sort of parallelism between the values of the group, practiced and recognized by its members, and official state values, which are relevant for those communities only when they concern general or national interest". In any case, a political subculture has a matrix, a pattern conferring an identity, a personality to the collectivity and political organization. The identity of a political subculture can be based on its 
Iovan, M., (2015)

The political culture; political socialization and acculturation

ethnic heritage (the culture promoted by the Roma Party, by U.D.M.R. etc.), on its economic condition (the political culture of the aristocracy, of ghetto paupers, the culture promoted by the middle class party etc.), on the affiliation to a certain region (the political culture promoted by the Moldovans' Party, the political culture of $18^{\text {th }}$ century Transylvania, or the Basque Country etc.) and to history (frequently invoked in leaders' speeches).

Political subculture possess a distinct language, specific symbols (logos, banners, coats of arms, ceremonies, portraits of the leaders, colors, anthems, uniforms, myths, slogans, greeting phrases, distinct forms of communication, meant to strengthen feelings of identity and protect this communication from outsiders).

At the same time, apart from political subcultures, there may also be countercultures, political cultures marginalized by the regime, which openly, sometimes even vehemently contest the official political practice, the dominant values of society, often proposing radical institutional changes. Such are the extremist political cultures (ultranationalism, extreme right wing, the Neo-Nazi movement in Germany, the Ku Klux Klan in the United States of America, Al Qaeda, the Muslim Brotherhood in Egypt etc.). All these formations have developed their own cultural patterns, expressed in ideas, values, norms and styles of actions, opposing them to the cultures of their own societies. Certainly, the manifestation of political countercultures has official and very strong limitations in totalitarian regimes (in such political systems, countercultures are outlawed, their bearer and agents frequently come into contact with the repressive bodies of the state, countercultures are silenced or manifest themselves in latent forms). In democratic regimes, political countercultures have a wide space of expression, knowing the fact that the rightful state does its duty and that, at the same time, there are forms of tolerance and even respect for the cultural styles that may appear unnatural or outlandish.

The mosaic created by the existence and competition of political cultures may be considered a factor of progress for the political society. A part of the political forces are aware of this reality and stimulate it through practical means. The United States, France etc., have often considered that the diversity of their political culture improved their image in the world, increased their power (but not all of the citizens of these states share this opinion). On the other hand, some states (no dictatorial state is an exception to this) believe that the diversity of political subcultures comes to weaken the official political culture, and inhibit its functions. For this reasons they do not encourage such cultures or, often times, officially prohibit them.

The cohabitation of several political cultures (be they subcultures or countercultures) within the same society suggest the existence of great difficulties for those who wish to establish a hierarchy, to opt for "the best one", or to decide which one it "bad". Therefore, there is a relativism of political culture (the supreme practical value of opportunists), according to which any of the cultures plays a

DE GRUYTER OPEN
Journal of legal studies Volume 16 Issue 29/2015 ISSN 2392-7054. Web: publicatii.uvvg.ro/index.php/jls. Pages 26 - 47 
distinct role, has function in the overall configuration of society culture, feeds on the culture of the social aggregate. The idea of relativity must not be pushed into cynicism or into the belief that anything is permitted in a political society, that there are no absolute standards (for instance, respecting the right to life, fighting racism etc.). Adopting a position of cultural relativism encourages citizens to have a more objective view of the society in which they live, the existing cultural styles, by relating them to their own potential.

Political culture is expressed in the actions of political agents (bodies of the state, parties, pressure groups, political leaders, the citizens' electoral behavior etc.). The series of historical political actions coherently refer to the entire culture, political culture in particular, mastered by political agents, resulting in different styles of political action. The political style (of a leader, a party or pressure group) externalizes the ideals, values, projects and norms to which the political agent adheres, giving it a certain personality and power of influence. The style of a political agent is their culture in action, their political civilization.

\section{Ideologies, vectorial and dynamogenic components of political culture}

Ideologies have been an integral part of political culture, of the culture of humanity in general, since the moment when social consciousness appeared. Ideologies consisted of sets of collective beliefs, attitudes, values, norms and representations, justified by reasoning, theorizations, doctrinal constructs that are more or less successful from a logical and scientific point of view. Ideologies have always been different: they may be religious, economic, political, juridical, moral, philosophic, esthetic etc. Their common denominator lies in the fact that they set out to reflect a segment of reality, to which the authors of their ideas and representations belong themselves, in terms of position, a attitudes, interests and traditions; ideologies attempt to provide a feeling of security to the agents of social action, in their effort of developing self-awareness, of gaining possession over some standards of coherent explanation of their place and role in society, of defining interpretations and justifications for their own deeds and for the relationships with other agents, believing them to be legitimate even in virtue of the promoted ideology.

The concept of ideology acquired a particular meaning in the thoughts of Marx and Engels. In the initial acceptation given to it by them, ideology would be illusory, mystified, alienated reflection of social evolution, a discourse which dissimulates reality or disguises certain segments of truth; it would be a false consciousness with regard to human-nature and human-human relationships, determined by class interest and the historical limits of the era in which social agents act. Subsequently, the connotation of the concept of ideology was extended to the entirety of ideas and outlooks reflecting, in a more or less systematized form, the interests and aspirations of the members of a social class or stratum, determined by the objective conditions of their existence and which serves to justify, consolidate or change 
The political culture; political socialization and acculturation

social relationships, that specific class being interested in maintaining or creating these relationships. In agreement with this connotation, a recent book stated that "an ideology is a systematized and relatively hierarchic set of opinions... the term of "doctrines" is often preferred to that of "ideologies", which is attributed an exclusively negative connotation... In fact, the concept of ideology is more general than that of doctrine, being a universalistic way of interpreting reality, from which derives the interpretation of political reality. From this perspective, it is believed that there are only three fundamental political ideologies -conservatism, socialism and liberalism, the rest derived and combined, theoretically or historically from them". Another, widely recognized, author believed that "an ideology would indeed be a pseudo-science and a pseudo-philosophy, transgressing at the same time the limitations of science and the limitations of philosophy...ideologies pretend to know the mysteries of the whole historical process - the secrets of the past, the intricacies of the present, the uncertainties of the future." In such an acceptation, ideologies are created by intellectuals who have a doctrinal, "advocational" vocation (in the sense that they have the ability to defend particular interests, that they know how to construct an discourse depending on the identity of a particular collectivity); they contain a high degree of correspondence with the reality to which they refer, but also inadequate, incoherent, false and unscientific reflections, justifications, and evaluations. The same aspects remain true for the judgments of value contained by any ideology (judgments of value express the options and desires of the agent, their attitude toward other social agents etc.); all these can have a very different base or sufficient reason, going as far the most aberrant evaluations. The way in which judgments of existence are combined with judgments of value, the proportions between the adequate and the inadequate reflection of reality, between truth and falsehood differ from one ideology to another.

A particular variant of the concept of ideology is represented by political ideologies. The latter express, in a theoretical-justifying plane, by relating to certain values and norms with particular connotations, the attitudes, interests, feelings and volition of political agents and the social group they represent, towards the state, evolution and prospects of global society, towards the ratios of power and domination. Political ideologies are, therefore, a component of the political agents' self-awareness, having a guiding, regulating, ordering function for political behavior; they offer axiological landmarks, general projects regarding the evolution of individuals and society as a whole, in order to shape the preparation of political agents' agenda, strategies and tactics. From this perspective, ideologies are the most evident component of political culture, guiding the history of political practice. Dominique Colas was convinced that "ideology is an element of culture, an even its hard nucleus, as it defines it explicitly, systematically and essentially". Therefore, political ideologies are dependent on political action, are integrated into 
the life of political agents, as vectors of political struggles, proposing the introduction of a new socio-economic order, a new course in political and social life. From this perspective, they either suggest and describe a desirable social order, or bring justification to interests and projects for their accomplishment, or condemn the ideas and practices of competing political agents, especially those of opposing orientation. Political ideologies are promoted both by the representatives of power, as justifying discourses of the power exerted by them, and by the representatives of the opposition, as discourses opting for a new political order and destructively criticizing the existing order and political-juridical practices for supporting it. Consequently, any political ideology will contain attitudes and "for" or "against" options, will have in itself a theoretical elaboration of a constructive-justifying type, and another one of a destructive-critical type. Political ideologies are, therefore, at the same time, not only "discourses" of power or against power, but also resources, instruments, "weapons" of political practice, of political socializations and media coverage.

As veritable guides of collective action, political ideologies "describe social order, condemn or justify it. In this sense, they are related to origin narratives, to the myths of traditional societies. But, differing from myth, ethic - religious, Messianic or prophetic doctrines, political ideologies take the form of a demonstrative argumentation targeting the establishment of a necessity for political order or the ineluctable character of its evolution. They are the natural offspring of industrial and postindustrial society, dominated by the scientific way of thinking. However, they are clearly different from science. Ideologies do not accept the overturning of their "arguments", based on a progress of knowledge. They constitute closed and fixed systems of thought, addressing not only the people's reason, but also their affectivity".

From the above-mentioned it can be concluded that political ideologies are prescientific ways of reflecting social life, by which social group, human collectivities reach a more or less reality-deforming self-awareness, containing certain amounts of syncretic, primitive, infantile thinking, expressed in the form of myths, imaginary constructs, elements of false knowledge. With all of these "vices" political ideologies have promoted, in many cases, general human values; their propagation among crowds, among the civil society, has led to a stronger consensus, to social cohesion, to a more tightly knit political community. Political ideologies that rose to mainstream, to the backdrop of deeper social ruptures, of historical society-restructuring processes (through revolution, wars, great reform etc.), have served as platforms for legitimating a historical political practice, the settlement of political alliances, a political power, or the overthrowal of a political regime.

Today's political doctrines are numerous: liberal, social-democrat, socialist, Christian-democrat, ecologist, conservative, nationalist, communist, feminist etc. 
Iovan, M., (2015)

The political culture; political socialization and acculturation

From these derived several variants, dissidences, "hybrid" doctrines (resulting from the combination of two or more doctrines). As a consequence, political ideologies were classified into: left-wing, center and right-wing; conservative, reforming and revolutionary; royalist and republican; materialistic and idealistic; slave-based, feudal, capitalistic, communist; traditional, modern and postmodern; individualistic and collective etc. A recent classification (by Guido Dericks) uses as criterion the distinction between community and society - a historical process which strongly asserted itself from the $19^{\text {th }}$ century onwards. In this sense, the political doctrines that justify the interests of a particular human community, in competition with others, are: nationalism, conservatism, environmentalism, and those pleading for a universal society, for European construction and global regulation of international relations are liberalism and social-democracy. On the substance, they are also the most powerful contemporary political creeds, currents of opinions and political ideologies dominating collective mindset and imagination.

\section{Political socialization and acculturation}

As soon as a human being comes to life, it begins to capitalize on its social potential, engaging into a continuous process of interaction with its fellow humans, learning, broadening its cognitive and social experience, using a wide range of skills enabling it to actively participate in society. This important process by which the individual gradually learns new social roles, by which it develops its own identity and manifests itself as an active member of society, is called socialization. Over the last few decades, numerous definitions were given to the process of socialization (from the perspective of psychology, sociology, sociology of deviance, culturology, cognitive theory, symbolic interaction). Most authors regard socialization as an ontogenetic, stage process, consisting of the entirety of formative-educative influences exerted by various social groups on individuals that compose them. Through this process individuals assimilate the language, values, habits, traditions, customs, attitudes, norms, and rules of behavior that are specific to the social group to which they belong. The normal development of human beings requires inter-individual contacts, occasions to see, hear and learn from one's peers, closeness and communion with other human beings. Formative, educative, shaping influences come from formal and informal agents are wittingly or spontaneously produced, generating, for the developing personality, mechanisms of assimilation, choice, learning, adaptation, integration, conformity or nonconformity to the requirements of the social, political-juridical and moral environment.

The first instances of socialization, implicitly political, are through family (most importantly), school and church, age group, mass-media; then there are friend circles, colleagues, army, frequented institutions, partisanship etc. According to sociologist Norman Goodman, "the one truly important factor in socialization is family. Family is 
the first and most continuous social world to the infant and the child. It is within family that the first and most durable intimate relationships are established. The communicative capacity, first occurring by learning the language, initially also takes place in family. Also in family, the infant and the child come to know the key elements of culture ... family provides the initial social identity of the child in terms of race, religion, social class and gender. The general chances in life, health, longevity, degree of education and type of occupation are strongly influenced by the family in which the child is born". But the family environment will also determine the child's socialization, along with the other factors.

A large part of American researchers reached the conclusion that individuals' integrating into groups and social collectivities is the result of three factors:

a) assimilation, internalization of juridical and moral norms, role models and values;

b) the individual becomes aware of the fact that possibilities of choice from assumable roles are limited;

c) the human being acquires the consciousness of responsibility for the way in which it abides by ethical-juridical norms, in virtue of which it avoids punitive sanctions naturally deriving from the infringements of these norms and, at the same time, wishes to obtain more prestige and positive feedback from complying with the ethical-juridical model provided by society.

During an individual's socialization process, social control will lead conduce to the acceptance and internalization of the values, goals, norms, habits and mentalities of the collectivity, social control gradually transforms into self-control, into free action by individuals, who will reproduce, often creatively, the cultural-normative pattern of society. Essentially, socialization has the effect of creating conformist personalities, which will manifest predictable behaviors, integrated into social system. But socialization is a dynamic, open product, not lacking in ambivalent implications, because the individuals will not confine themselves to mechanically learning conformity with relation to the values and norms of collectivity, they will not linearly comply with its requirements, but will learn to compare, to choose, contest, reject certain patterns out of those provided by society. For this very reason, R. Linton, E. Sapir, A. Kardiner etc. replaced the term of socialization with that of acculturation, emphasizing the importance of assimilating values and goals, cultural patterns.

Political socialization is a facet of the individual's overall socialization process, of assimilating the culture of society, having a specificity among socializing processes in the fact that it ultimately leads to the formation of those skills of the human being which, in its quality as a citizen, will enable it to make a distinction between civil society and political society, to understand and evaluate political facts, to make political options and participate in solving political affairs, according to the statuses and roles assimilated by each. Political socialization is a complex, 
Iovan, M., (2015)

The political culture; political socialization and acculturation

multiphasic process for forming and developing the political culture of individuals, for assimilating roles that render them capable of participating in political life.

Political socialization, as socialization in general, is not a process of "sociopolitical dressage", it does not consist of a mere reception and passive acceptance of elements of political-juridical culture passed on by mature generations; it involves an ample personality shaping process, sustained efforts of social learning throughout and individual life, observably resulting in political-civic behavior, the human being's participation in political life. It does not confine itself to the storage of political knowledge and information, nor to the formation of skills for valuating political facts and for orienting oneself in the political realm, but, to a greater extent, it is an exercise in practicing political, participative behaviors, in externalizing one's personality through attitudes of acceptance or non-acceptance of political decisions, by making options, by actively propagating elements of political culture in favor values on which personality is based, by directly participating in leadership activities etc.

Schematically, the liberal and radical outlooks on political socialization present themselves as follows:

\begin{tabular}{|c|c|c|c|c|}
\hline & From whom to who & Main institution & $\begin{array}{c}\text { Prevalent } \\
\text { period of time }\end{array}$ & How? \\
\hline $\begin{array}{l}\text { Liberal } \\
\text { outlook }\end{array}$ & $\begin{array}{c}\text { From one generation to } \\
\text { another }\end{array}$ & Family & Childhood & $\begin{array}{c}\text { Unplanned } \\
\text { (spontaneous) }\end{array}$ \\
\hline $\begin{array}{c}\text { Radical } \\
\text { outlook }\end{array}$ & $\begin{array}{c}\text { From the dominant class } \\
\text { to the subordinate class }\end{array}$ & Mass - media & $\begin{array}{c}\text { Adult age and } \\
\text { childhood }\end{array}$ & Premeditated \\
\hline
\end{tabular}

The process of political socialization begins as early as the period of childhood, within formal and informal groups (family, kindergarten, age group, mass-media, circle of friends, Church etc.), having a strong affective support.

Psychopedagogues have succeeded in determining the moment when politicojuridical socialization starts: ate age 5-6, when some basic processes in the structure of personality begin to take shape. In childhood does basic (or primary) socialization occurs which is then added, during adulthood, continuous political socialization, conditioned by the adult's assumption of new initiatives and roles by which their citizen status is materialized. The content of socialization differs according to the ontogenetic stage, to the profile, purposes and values of the groups adhered to by the human being. The child is socialized within a profoundly affective context (family), and the adult in usually interested environments, with their lives centered on specific values, goals and norms. The adult will receive and assimilate the political culture of the group (the social class to which they belong, the collectivity, the community etc.), by relating to the official political culture, to 
the values of dominant institutions in society.

Continuous socialization (also called "secondary" by some sociologists) or the political socialization of adults regard those processes by which citizens assume new political roles which intersect to political life, associated to the assimilation of corresponding elements of political culture, to the de-structuring of political attitudes, the re-orientation of personality towards new political values. The main causes of political re-socialization may act from within the personality (political disillusion, loss of hope, contradiction between initial expectations and the performance of the political regime, the feeling of duty, the need for social prestige etc.) or may be due to external constraints: the change of political regime, becoming unemployed, changing one's professional status, retirement, passage of laws profoundly affecting citizen interests etc. Adults' political socialization process is a sinuous, contradictory, personalized one, often containing personal dramas caused by the difficulties of changing political convictions and attitudes, and restructuring one's own hierarchy of political values etc. News acquisitions of political culture may enter into conflict with the old values and norms, resocialization occurring with a certain degree of difficulty, directly proportional to age.

Political socialization largely coincides with political education in a broader sense (exerted by family, school, university, mass-media, other educational factor), but has a wider scope by its contribution, as well as that of other institutions (political, economic, juridical, religious organizations etc.) or factors of spontaneous, random influence. Some political institutions create possibilities, especially for their members, of preparing for the role they will practice later, for future positions in the world of political elite, which is called anticipated socialization or presocialization.

According to the degree of conformity to the values of the political system and the contribution to political-juridical innovation, socialization may also be positive or negative. Positive political socialization essentially presupposes conforming to the values of the system, to the official ethical-political model, manifesting a creative, innovative conduct within the system and not against it, whereas negative political socialization consists of assimilating a different type of political culture, leading to the marginalization of those persons with regard to the official political culture, to the development of a counterculture oriented by values opposed to the existing political-juridical system (for example: socialization within protest groups, political dissident movement, formations opposed to the politics of the regime etc.).

Depending on how it is done, political socialization may be latent (informal) and manifest (institutionalized, formal); conscious and unconscious; cognitive, affective, attitudinal, volitional and creative. These variants of socialization may enter diverse combinations within the complex process of political acculturation a process resulting from the contacts and interaction between two or more political 
Iovan, M., (2015)

The political culture; political socialization and acculturation

cultures. Political acculturation is the entirety of changes occurring in original cultural patterns, when groups of people with different political culture come into contact on a long-term basis. Political cultures that come into contact will undergo intrinsic changes, re-elaborations, reciprocal exchanges, borrowings, adjustments etc. Thus, for instance, in times of invasions, colonial conquest, international migration, immigrant exodus in the European Union or in the USA, forms of political acculturation always take place, but none of the political cultures involved succeeds in completely dominating the other, even if inequalities, amplitudes, axiological differences between them are very evident. In his sense, M. Dogan and D. Pelassy wrote: „Political culture is transmitted by acculturation. Thus, socialization assumes a function of stabilization in a vertical sense between generations, as well as a horizontal sense - between social groups".

The efficiency of political socialization has increased enormously over the last half of a century, due to the development of systematic, theoretical and scientific political culture, of the exponential growth in the number of specialists with expertise in the field and especially media and mass-media development experts (remote communication through televisions, the Internet, mobile phones etc.).

An example of forced political-juridical socialization was that undertaken by Spanish conquistadors in Central and South American territories, which they conquered, introducing political, juridical and religious control accompanied by the use of force, then followed by imposing the political and normative model issued by the Iberian civilization, by political re-socialization. In all cases, colonization introduced the political culture of the metropolis, its juridical and economic model, gradually criminalizing traditional norms and rules of conduct. The same line was followed by numerous communication operations of the dominant culture or of cultural models "embodying" democracy, including those affecting, over the last few years, the population of Iraq, Afghanistan, Serbia, Iran etc. But re-socialization also affects the invaders who often find themselves in the situation of revise their attitudes, to recognize the value of some element of the political culture of the invaded etc. Sometimes, political acculturation determines a certain type of socialization which can evolve between two axes: cultural integration, which makes the elements of foreign culture be incorporated into the indigenous politicalsocial system, according to its cultural matrix, and assimilation, as an inverse process of adopting political-juridical values and norms, accompanied by the elimination of indigenous traditions and mentalities.

\section{Instead of conclusions}

In the period following the collapse of communism in Eastern Europe, there is an acute issue of forming and developing a political culture specific to democracy, in close agreement to universal values, which would facilitate the active, responsible participation of citizens in political life. Radical changes in the post-1989 political

DE GRUYTER OPEN 
system and regime, and the adoption of a new set of political values impose a necessity for political re-socialization of citizens - a particularly complex and sinuous process, charged with true subjective dramas, not always followed socially acceptable results. This type of process brings back into current interest the older issue and theory "forms without a substance", coined in Romanian culture by Titu Maiorescu. He had noticed the discordance between political institutions, juridical codes, initiatives of reforming the political state organizations introduced in Romania during the second half of the last century and the economic-social structures, traditions, customs and spiritual substance of the people. The greatest vice of politicians back then was their unrealistic creed that the forms that were copied from the wealthy and civilized Western Europe would be appropriate and productive in Romania. But, in reality, as T. Maiorescu asserted, these were dead productions, baseless pretentions, forms that had no sufficiently matured premises in national culture and economic life. Is this question not the same today? Are we prepared "to enter Europe definitively"? Is the creation of institutions specific to democracy, most of all the adoption of a democratic Constitution and the dissemination of rule-of-law ideology, a sufficient condition? Will collective mentality, attitudes, skills and habits formed throughout several decades of totalitarian political life be replaced overnight? Will the assumption of the political outlooks of Western institutions be supported and effectively realized (implicitly at the level of political attitudes and behavior) by the entire people or only by the elites?

Such issues emanate from the specific practices of Romania's evolution towards a consolidated market economy and towards a mature democracy demonstrating that institutions, laws, the Constitution, however well they were designed, are sufficient in themselves for the rule of law to become a reality or for market economy to become a source of progress and wealth. As long as laws, governmental practices, created institutions will remain external to the political life and culture of most citizens, as long as citizens will remain indifferent, apathetic to reforming changes, Maiorescu's theory will continue to be topical, that is, the performance of the political regime will not meet the expectations of civil society. This serves to show how important is the political re-socialization of citizens, the generalization of political-civic culture matching the concrete realities in Romania, the construction of active, rational political attitudes involving the responsibility of common citizens. But forming a political culture involving the participation of ordinary people takes time, sometimes even generation; it is, first of all, a certain result of political pedagogy and civic education. Political education, engaging the contribution of various socialization institutions, may speed up the reform process, may achieve the required correlation between political-juridical institutionalization and the spiritual substance, collective mentality and political-civic culture of the masses, thus facilitating the efficiency of operating a democratic political system. 
Iovan, M., (2015)

The political culture; political socialization and acculturation

On the substance, political education and socialization do not lead to uniform attitudes among citizens, to leveling their political culture, to generalizing the predominant ideology or to decreasing the number of existing political cultures in a society or on the territory of a state, but to the increase in the level of an individual's knowledge of political life, to the development of their capacity to explain to themselves and to others the political events and trends in their community or state and in the world, to the formation of skills for orienting themselves in the political realm, for evaluating public policies, events and decision taken by authorities, in order to choose and decide about their participation and involvement in politics, to the development of self-awareness by relating to the political orientations and strategies circulating in society, which will allow them to leave the state of neutrality or political apathy and become an active participant in solving of the issues of their community, in accordance to a creed resulting from internalizing the political values of $21^{\text {st }}$ century democracy. „Being at east everywhere and in any circumstance is an indicator of success for socialization" - Yves Schemeil wrote, with good reason.

Indeed, political socialization, formal and informal political education, especially those occurring before the individuals starts to mature, find their ultimate completion in the personality profile of zoon politikon, characteristic of the beginning of the $3^{\text {rd }}$ millennium. The citizen of this age of history, whether governor or governed, must come to possess a personal political culture that would internalize universal values decreed throughout two millenniums in European culture, the current senses and significations of political culture, associated to the feeling of their responsibility for the community they belong, of solidarity, justice and freedom as a motivating factor for participative behaviors. 